Article

\title{
Evaluation of the Scaffolding Effect of Pt Nanowires Supported on Reduced Graphene Oxide in PEMFC Electrodes
}

\author{
Peter Mardle, Oliver Fernihough and Shangfeng Du * $\mathbb{D}$ \\ School of Chemical Engineering, University of Birmingham, Edgbaston, Birmingham B15 2TT, UK; \\ PJM556@student.bham.ac.uk (P.M.); OXF537@student.bham.ac.uk (O.F.) \\ * Correspondence: s.du@bham.ac.uk; Tel.: +44-121-415-8696
}

Received: 1 January 2018; Accepted: 22 January 2018; Published: 25 January 2018

\begin{abstract}
The stacking and overlapping effect of two-dimensional (2D) graphene nanosheets in the catalyst coating layer is a big challenge for their practical application in proton exchange membrane fuel cells (PEMFCs). These effects hinder the effective transfer of reactant gases to reach the active catalytic sites on catalysts supported on the graphene surface and the removal of the produced water, finally leading to large mass transfer resistances in practical electrodes and poor power performance. In this work, we evaluate the catalytic power performance of aligned Pt nanowires grown on reduced graphene oxide (rGO) (PtNW/rGO) as cathodes in $16-\mathrm{cm}^{2}$ single PEMFCs. The results are compared to $\mathrm{Pt}$ nanoparticles deposited on $\mathrm{rGO}(\mathrm{Pt} / \mathrm{rGO})$ and commercial $\mathrm{Pt} / \mathrm{C}$ nanoparticle catalysts. It is found that the scaffolding effect from the aligned Pt nanowire structure reduces the mass transfer resistance in rGO-based catalyst electrodes, and a nearly double power performance is achieved as compared with the $\mathrm{Pt} / \mathrm{rGO}$ electrodes. However, although a higher mass activity was observed for $\mathrm{PtNW} / \mathrm{rGO}$ in membrane electrode assembly (MEA) measurement, the power performance obtained at a large current density region is still lower than the Pt/C in PEMFCs because of the stacking effect of rGO.
\end{abstract}

Keywords: PEMFC; nanowire; graphene; PtPd; 2D

\section{Introduction}

With the commercial release of the Toyota Mirai and Hyundai ix35 fuel cell vehicles, the viability of using proton-exchange membrane fuel cells (PEMFCs) as the power source in transport applications has been demonstrated. However, for the widespread adoption of such vehicles, larger power outputs and long-term durability are required at a reduced cost [1,2]. Due to the sluggish oxygen reduction reaction (ORR) at the cathode in PEMFCs, catalysis is required. Platinum group metals (PGM), and specifically platinum $(\mathrm{Pt})$, are inherently the most active catalysts towards the ORR [3] as well as the most stable in the acidic conditions of the PEMFC. However, due to their high cost and low performance compared to theoretical values, much effort has been directed to developing novel methods of reducing the PGM content while increasing the catalytic activity [4].

One-dimensional (1D) Pt nanostructures such as nanowires and nanotubes have received increasing interest in recent years [5]. Sun et al. synthesized Pt nanowires supported on carbon black (PtNW/C) by the simple wet chemical route of using formic acid to reduce chloroplatinic acid to $\mathrm{Pt}$ metal [6]. This catalyst demonstrated enhanced ORR activities as the favored Pt growth along the (111) crystallographic plane promoted by the slow reduction rate, and the regular arrays improved the intrinsic catalytic activity and mass transport limitations, respectively. This theory has been supported by Du's group, in whose work the synthesis conditions were optimized for the in situ growth of PtNWs directly on carbon paper gas diffusion layers (GDLs) $[7,8]$. 
To help maximize catalyst utilization ratio in PEMFC electrodes as well as improve stability, PGM catalysts are commonly supported on carbon blacks [9]. High surface area carbon blacks such as the Vulcan XC-72R are typically used due to the large catalyst electrochemically active surface areas (ECSA) obtainable from the provided porous network. However, a caveat of the porous network is the fact that many PGM catalyst particles can become trapped inside nanopores, where electrolyte ionomer cannot access them to form effective active sites. Carbon blacks also suffer from carbon corrosion due to the relatively low oxidation potential of carbon [10]. In an attempt to address these issues as well as in order to minimize charge transfer resistances in the catalyst layer, various carbonaceous supports such as carbon nanotubes (CNTs), carbon nanofibers (CNFs) and graphene have been investigated [11-13]. Of particular interest is the reduced graphene oxide (rGO), wherein the impurities from incomplete reduction provide much needed nucleation sites on the otherwise pristine graphene sheets. These functional groups have also been shown to help improve the carbon monoxide poisoning tolerance of the impurity in fuel cell gases as well as enhance reaction activities [14-16].

In combining the two areas of interest, PtNWs have been grown on rGO supports [14] as well as sulfur-doped graphene (SG) [17]. Although the latter referenced work showed an even distribution of nanowires on the rGO supports, branched nanowires formed to the anchoring oxygen functional groups. To help address this issue, Du et al. [15] introduced palladium (Pd) nanoseeds onto PVP-functionalized rGO sheets to grow uniform PtNWs. With improved distribution on the entire rGO surface, uniform nanowires were demonstrated to lead to enhanced catalytic activity.

However, the two-dimensional (2D) nature of the graphene-based catalysts makes them very difficult to use in practical electrodes in PEMFCs. In the drying process of the catalyst layer made by coating rGO-based catalyst inks, the rGO nanosheets stack on top of each other to form a dense catalyst layer, exacerbating the mass transfer limitations for both the reactant fuel and the produced water diffusing through the layer [16,18]. Considering the encouraging ORR catalytic activities of $\mathrm{PtNWs} / \mathrm{rGO}$, the intention of this work is to evaluate the scaffolding effect of the unique PtNWs/rGO structure by in situ testing in single PEMFCs. Fuel cells with cathodes from Pt nanoparticles supported on $\mathrm{rGO}(\mathrm{Pt} / \mathrm{rGO})$ and commercial $\mathrm{Pt} / \mathrm{C}$ nanoparticle catalysts are also fabricated as benchmarks to help understand the stacking effect of rGO nanosheets and the enhanced scaffolding effect from the nanowire geometry.

\section{Materials and Methods}

\subsection{Materials}

Poly(N-vinyl-2-pyrrolidine) (PVP-K30, molecular weight $=30,000-40,000), \mathrm{H}_{2} \mathrm{PtCl}_{6}$ (8 wt \% in $\mathrm{H}_{2} \mathrm{O}$ ), $\mathrm{PdCl}_{2}$, formic acid $\mathrm{HCOOH}$, Isopropyl alcohol (IPA) and L-Ascorbic acid were purchased from Sigma-Aldrich (Dorset, UK). The $\mathrm{PdCl}_{2}$ was dissolved in water to provide a solution of concentration $0.125 \mathrm{~g} \mathrm{~mL}^{-1}$. All other chemicals were used as received. The single-layer graphene oxide (GO) dispersion (thickness $0.43-1.23 \mathrm{~nm}$, diameter $1.5-5.5 \mu \mathrm{m}$, dispersed in water at $2 \mathrm{wt} \%$ ) was purchased from U.S. Research Nanomaterials, Inc. (Houston, TX, USA). Johnson-Matthey (JM) electrocatalysts with $20 \mathrm{wt} \% \mathrm{Pt}$ supported on carbon black (Pt/C $20 \mathrm{wt} \%$ ) was purchased from Alfa Aesar (Lancashire, UK). The water used throughout was purified with a Millipore (Hertfordshire, UK) system.

\subsection{Preparation of PVP-Functionalized $r G O$}

Two and a half milliliters of the $2 \mathrm{wt} \% \mathrm{GO}$ suspension were diluted with $197.5 \mathrm{~mL}$ of $\mathrm{H}_{2} \mathrm{O}$. The resulting dispersion was sonicated with a $130 \mathrm{~W}, 20 \mathrm{kHz}$ sonic horn at $40 \%$ amplitude for $30 \mathrm{~min}$. Then $800 \mathrm{mg}$ of PVP were added and the mixture was stirred for $12 \mathrm{~h}$. Next $200 \mathrm{mg}$ of L-Ascorbic acid were added to the mixture, which was subsequently heated to $95^{\circ} \mathrm{C}$. The mixture was then stirred for $1 \mathrm{~h}$ before centrifugation once with $\mathrm{H}_{2} \mathrm{O}$. The $\mathrm{rGO}$ was then dispersed in $\mathrm{H}_{2} \mathrm{O}$ to provide a $25 \mathrm{~mL}$ suspension. Two and a half milliliters of the as-prepared rGO suspension were diluted with $17.5 \mathrm{~mL}$ of $\mathrm{H}_{2} \mathrm{O}$. Two separate suspensions were prepared. 


\subsection{Preparation of $P t / r G O$}

The preparation of $\mathrm{Pt} / \mathrm{rGO}$ followed the process reported [19]. Two milliliters of the $\mathrm{H}_{2} \mathrm{PtCl}_{6}$ solution were added to one of the diluted rGO suspensions. Separately, $62 \mathrm{mg}$ of $\mathrm{NaBH}_{4}$ were dissolved in $20 \mathrm{~mL}$ of $\mathrm{H}_{2} \mathrm{O}$, which was added dropwise to the reaction mixture under sonication by a sonic bath. After $1 \mathrm{~h}$ of sonication time, the reaction mixture was left to settle overnight before being washed and collected by centrifugation in $\mathrm{H}_{2} \mathrm{O}$ twice, followed by once with IPA. The catalyst was dispersed in IPA to provide a suspension of concentration $5 \mathrm{mg}_{\mathrm{Pt}} \mathrm{mL}^{-1}$.

\subsection{Preparation of $\mathrm{Pt}(\mathrm{NW}) \mathrm{Pd} / \mathrm{rGO}$}

$\mathrm{Pt}(\mathrm{NW}) \mathrm{Pd} / \mathrm{rGO}$ was prepared following the procedure previously reported by our group [15]. Typically, $53.3 \mu \mathrm{L}$ of the stock $\mathrm{PdCl}_{2}$ solution was added to one of the diluted suspensions of rGO. Then $0.8 \mathrm{~mL}$ of $\mathrm{HCOOH}$ was added and the mixture was left to stir at room temperature for $16 \mathrm{~h}$. Afterwards, a further $40 \mathrm{~mL}$ of $\mathrm{H}_{2} \mathrm{O}$ were added, followed by $2 \mathrm{~mL}$ of the $\mathrm{H}_{2} \mathrm{PtCl}_{6}$ solution. Next $6.64 \mathrm{~mL}$ of $\mathrm{HCOOH}$ were added and the reaction mixture was left to react for $72 \mathrm{~h}$. Centrifugation and dispersion of this catalyst in IPA followed the same procedure detailed for $\mathrm{Pt} / \mathrm{rGO}$.

\subsection{Membrane Electrode Assembly (MEA) Preparation and Physical Characterization}

To obtain suitable catalyst loadings of 0.4 and $0.6 \mathrm{mg}_{\mathrm{Pt}} \mathrm{cm}^{-2}$ within electrodes, sufficient quantities of commercial $\mathrm{Pt} / \mathrm{C}, \mathrm{Pt} / \mathrm{rGO}$ and $\mathrm{Pt}(\mathrm{NW}) \mathrm{Pd} / \mathrm{rGO}$ suspensions were added to separate sample vials and $113 \mu \mathrm{L}$ of $10 \mathrm{wt} \%$ Nafion solution were added to each. In the case of $\mathrm{Pt} / \mathrm{C}, 0.875 \mathrm{~mL}$ of IPA was added to disperse the catalyst black. The catalyst inks were sonicated by a $130 \mathrm{~W}, 20 \mathrm{kHz}$ sonication horn for $10 \mathrm{~min}$ at $20 \%$ power. The gas diffusion electrodes (GDEs) were made by coating the catalyst inks through painting onto $16 \mathrm{~cm}^{2}$ Sigracet $35 \mathrm{BC}$ carbon paper gas diffusion layers (GDLs). After leaving them to dry at room temperature, the electrodes were hot-pressed to a $36 \mathrm{~cm}^{2}$ piece of Nafion ${ }^{\circledR} 212$ membrane at $1800 \mathrm{lb}$ load for $2 \mathrm{~min}$ at $135{ }^{\circ} \mathrm{C}$ with commercial JM Pt/C anodes with a catalyst loading $0.4 \mathrm{mg}_{\mathrm{Pt}} \mathrm{cm}^{-2}$. The GDE surface was imaged using a Philips (Amsterdam, The Netherlands) XL-30 FEG Environmental SEM operating at $20 \mathrm{kV}$.

\subsection{Single Cell Testing}

The MEAs were tested in a PEM fuel cell stand (FCT-50S, PaxiTech-BioLogic, Grenoble, France) with electrochemical impedance spectroscopy (EIS) capabilities. A polytetrafluoroethylene (PTFE) gasket of thickness $254 \mu \mathrm{m}$ was used at both the cathode and anode sides. The membrane was hydrated by holding the cell potential at $0.6 \mathrm{~V}$ for $14 \mathrm{~h}$ at the cell temperature of $80^{\circ} \mathrm{C}$. The reactant gases were fully humidified $\mathrm{H}_{2}$ / air at the anode and cathode, respectively, with a backpressure of $0.5 / 0.5$ bar and stoichiometry of 1.3:2.4, respectively. To measure the electrochemically effective surface area (ECSA) of the catalysts in the electrodes, the cathode gas was then switched to $\mathrm{N}_{2}$. After $30 \mathrm{~min}, 200$ cycles of cyclic voltammetry (CV) scan were conducted to the cathodes between 0.05 and $1.2 \mathrm{~V}$ at a sweep rate of $50 \mathrm{mV} \mathrm{s}^{-1}$, followed by three scans at $20 \mathrm{mV} \mathrm{s}^{-1}$. The third scan at $20 \mathrm{mV} \mathrm{s}^{-1}$ was used for the ECSA calculation. The cell potential was then held at $0.5 \mathrm{~V}$ for $30 \mathrm{~min}$ and the average current obtained was used for $\mathrm{H}_{2}$ crossover correction in the mass activity measurement in the MEA. The reactant gas at the cathode was then changed back to air and, after being held stable for $30 \mathrm{~min}$, the cell polarization curve was recorded at $1 \mathrm{mV} \mathrm{s}^{-1}$ between the open circuit voltage (OCV) and ca. $0.3 \mathrm{~V}$. Electrochemical impedance spectroscopy (EIS) analysis was run at $0.65 \mathrm{~V}$ in the frequency range $10 \mathrm{kHz}-0.1 \mathrm{~Hz}$ with an amplitude of $10 \mathrm{mV}$. To measure the mass activity of the catalyst in the electrode, the cathode was then switched to $\mathrm{O}_{2}$ gas and a polarization curve was recorded at $1 \mathrm{mV} \mathrm{s}^{-1}$ with fully humidified $\mathrm{H}_{2} / \mathrm{O}_{2}$ at stoichiometry of $2 / 9.5$, respectively. 


\section{Results}

\subsection{SEM Analysis of GDEs}

Figure 1 shows the surface SEM images of the GDEs made from $\mathrm{Pt} / \mathrm{C}, \mathrm{Pt} / \mathrm{rGO}$, and $\mathrm{Pt}(\mathrm{NW}) \mathrm{Pd} / \mathrm{rGO}$. The GDE with Pt/C nanoparticle catalysts displays many large cracks (Figure 1a) with a land size of several hundred micrometers, which is in agreement with our former research; these cracks are considered essential for gas diffusion through the whole catalyst layer, together with the mesoporous network formed by the high surface area carbon support (Figure 1b) [20]. When rGO is introduced, as shown in Figure 1c,e, the number of cracks significantly decreases. Both GDEs from $\mathrm{Pt} / \mathrm{rGO}$ and $\mathrm{Pt}(\mathrm{NW}) \mathrm{Pd} / \mathrm{rGO}$ exhibit a very similar structure. This change can be ascribed to the stacking of the rGO within the catalyst layer and the 2D rGO nanosheets overlapping with each other to form a much denser coating layer. Comparing with the one from $\mathrm{Pt} / \mathrm{C}$ nanoparticles shown in Figure 1a, this dense structure provides much less of a path for the gas diffusion through the catalyst layer, and thus a larger mass transfer resistance and a lower power performance is expected in the operation of PEMFCs. Figure $1 \mathrm{~d}, \mathrm{f}$ also show very few large aggregates on the electrode surface, demonstrating the good distribution of the rGO-based catalysts within the catalyst layer.
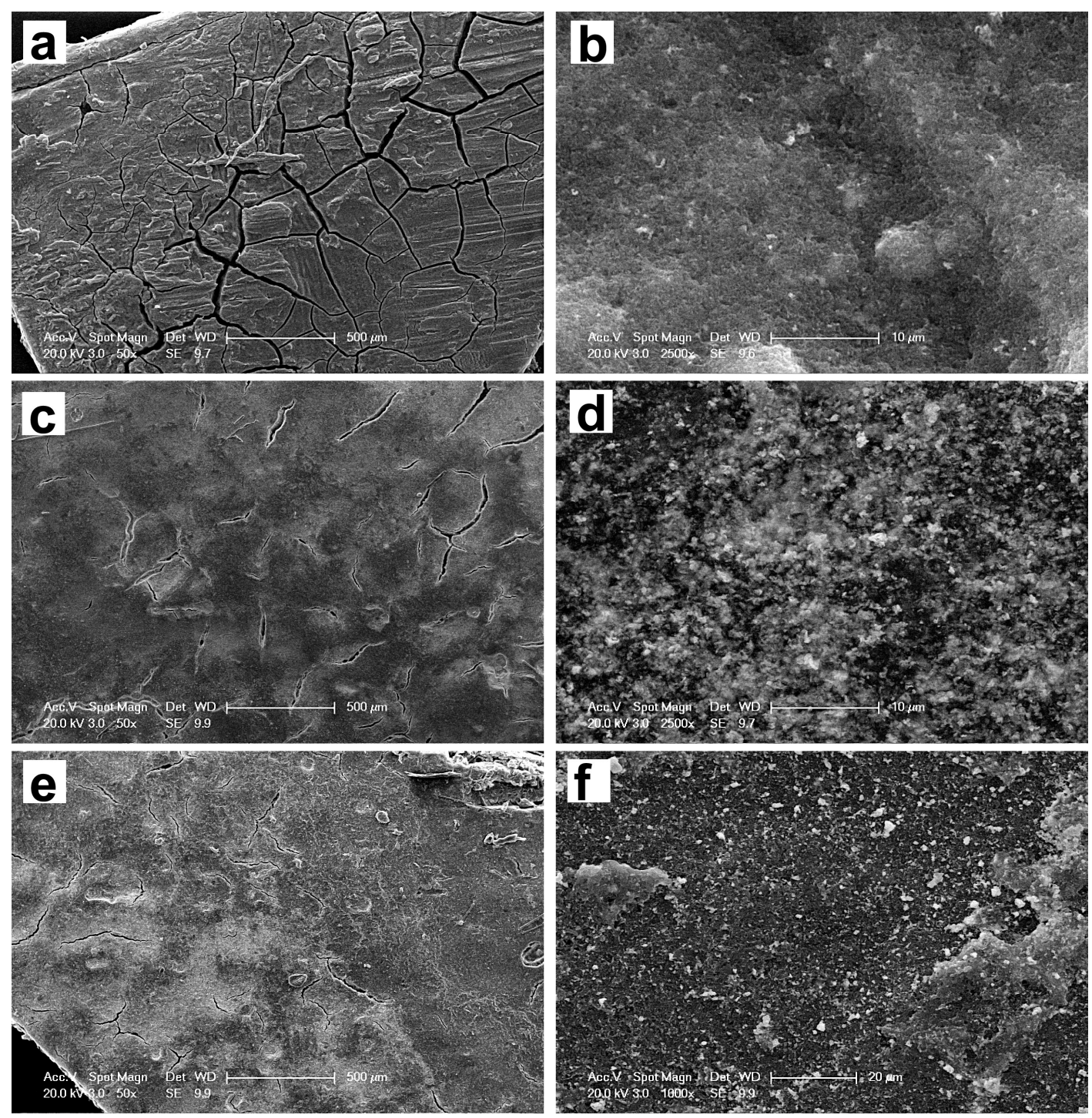

Figure 1. Surface SEM images of gas diffusion electrodes from (a,b) Pt/C 20\% (JM); (c,d) Pt/rGO and $(\mathbf{e}, \mathbf{f}) \mathrm{Pt}(\mathrm{NW}) \mathrm{Pd} / \mathrm{rGO}$ at a catalyst loading of $0.4 \mathrm{mg}_{\mathrm{Pt}} \mathrm{cm}^{-2}$. 


\subsection{In Situ Testing}

The GDEs were tested in $\mathrm{H}_{2}$ /air PEMFCs and the polarization and power density curves are shown in Figure 2. $\mathrm{Pt}(\mathrm{NW}) \mathrm{Pd} / \mathrm{rGO}$ shows a much higher power performance than $\mathrm{Pt} / \mathrm{rGO}$. At $0.6 \mathrm{~V}$, the conventional operation voltage for PEMFCs in practical applications, the power densities for the $\mathrm{Pt}(\mathrm{NW}) \mathrm{Pd} / \mathrm{rGO}$ and $\mathrm{Pt} / \mathrm{rGO}$ electrodes are 0.206 and $0.128 \mathrm{~W} \mathrm{~cm}^{-2}$, respectively, at a catalyst loading of $0.4 \mathrm{mg}_{\mathrm{Pt}} \mathrm{cm}^{-2}$. The high power density of the $\mathrm{Pt}(\mathrm{NW}) \mathrm{Pd} / \mathrm{rGO}$ electrode demonstrates the positive scaffolding effect from using nanowires. When increasing the catalyst loading from 0.4 to $0.6 \mathrm{mg}_{\mathrm{Pt}} \mathrm{cm}^{-2}$, the power performance for the $\mathrm{Pt}(\mathrm{NW}) \mathrm{Pd} / \mathrm{rGO}$ and $\mathrm{Pt} / \mathrm{rGO}$ electrodes increases very little-by only $9.7 \%$ or $3.1 \%$ to 0.226 or $0.132 \mathrm{~W} \mathrm{~cm}^{-2}$, respectively-indicating the mass transfer limitations within the practical rGO-based electrodes, as mentioned by Antolini [16]. The increase of catalytic activities of the catalysts within the electrodes cannot really convert to the improvement of electrode power performance in PEMFC devices. The enhancement observed for nanowire electrodes even leads to high power density over the $\mathrm{Pt} / \mathrm{C}$ nanoparticle electrode at a low current density range below $0.1 \mathrm{~A} \mathrm{~cm}^{-2}$. However, the power performance is still much lower as compared with the $\mathrm{Pt} / \mathrm{C}$ nanoparticle electrode at the large current density region, where a power density of $0.314 \mathrm{~W} \mathrm{~cm}^{-2}$ is achieved at $0.6 \mathrm{~V}$. The poor power performance with rGO-based electrodes is in line with the dense electrode structure shown in the SEM analysis in Figure 1.
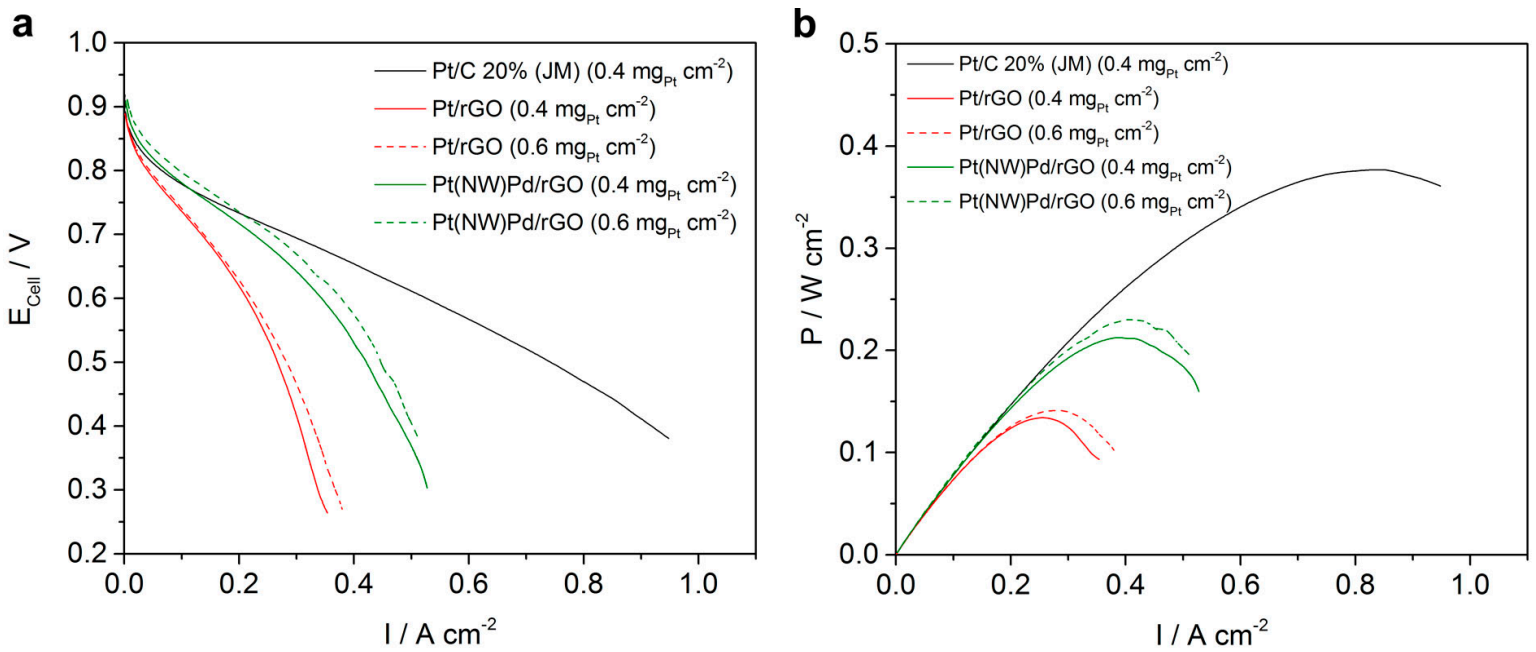

Figure 2. (a) Polarization and (b) power density curves obtained at a sweep rate of $1 \mathrm{mV} \mathrm{s}^{-1}$ at the cell temperature of $80{ }^{\circ} \mathrm{C}$. The reactant gases are fully humidified $\mathrm{H}_{2}$ at the anode and air at the cathode with backpressure of $0.5 / 0.5$ bars and stoichiometry of $1.3 / 2.4$, respectively.

To further understand the mechanisms behind the obtained performances, detailed analyses were conducted to obtain the ECSA, mass activity, and EIS of the involved electrodes (Figure 3); the results are summarized in Table 1 . An acceptable ECSA value of $19.84 \mathrm{~m}^{2} \mathrm{~g}^{-1}$ is obtained for the $\mathrm{Pt} / \mathrm{C}$ electrode, which is ca. $1 / 3$ of the value obtained in the liquid half-cell rotating disk electrode (RDE) measurement (ca. $50-70 \mathrm{~m}^{2} \mathrm{~g}^{-1}$ ) and in line with values reported in the literature $[15,19]$. However, the ECSA values observed for rGO-based electrodes are extremely low. By RDE measurement, the ECSA values obtained for $\mathrm{Pt} / \mathrm{rGO}$ are usually similar to or even higher than $\mathrm{Pt} / \mathrm{C}$ nanoparticle catalysts, but the value obtained here in the MEA is only $2.65 \mathrm{~m}^{2} \mathrm{~g}^{-1}$, which is much lower than that $\mathrm{Pt} / \mathrm{C}$ in the electrode. This lower ECSA for Pt/rGO further indicates a very low catalyst utilization ratio in the electrode (defined by the ratio of the ECSA observed in the electrode to the value by RDE measurement), ca. $5.45 \%$, taking into account the ECSA value of $48.62 \mathrm{~m}^{2} \mathrm{~g}^{-1}$ reported by the RDE measurement [19], resulting from the stacking and overlapping of the rGO nanosheets in the catalyst layer. For the $\mathrm{Pt}(\mathrm{NW}) \mathrm{Pd} / \mathrm{rGO}$, the ECSA value drops from $19.07 \mathrm{~m}^{2} \mathrm{~g}^{-1}$ by RDE measurement [15] to $2.97 \mathrm{~m}^{2} \mathrm{~g}^{-1}$ here. Although the utilization ratio is still low, ca. $15.59 \%$, it has been much higher than 
$\mathrm{Pt} / \mathrm{rGO}$, resulting from the scaffolding effect of the nanowires. However, the utilization ratio is still much lower as compared with the $\mathrm{Pt} / \mathrm{C}$ nanoparticles. In addition, an increase of the catalyst loading from 0.4 to $0.6 \mathrm{mg}_{\mathrm{Pt}} \mathrm{cm}^{-2}$ leads to slightly reduced ECSA values, resulting from the mass transfer limitation mentioned above. The mass activity in the MEA was measured under pure $\mathrm{O}_{2}$ rather than air to reduce the influence of the mass transfer resistance in the catalyst layer [1,7]. The standard measurement protocol defined by the U.S. Department of Energy (DOE) was followed [1]. However, this test under oxygen still does not work very well for the Pt/rGO electrode, and a much lower mass activity of $0.016 \mathrm{~A} \mathrm{mg}_{\mathrm{Pt}}{ }^{-1}$ is observed as compared with $0.041 \mathrm{~A} \mathrm{mg}_{\mathrm{Pt}}{ }^{-1}$ for Pt/C. A similar value is also obtained for the catalyst loading at $0.6 \mathrm{mg} \mathrm{cm}^{-2}$. For $\mathrm{Pt}(\mathrm{NW}) \mathrm{Pd} / \mathrm{rGO}$, this value reaches $0.044 \mathrm{~A} \mathrm{mg}_{\mathrm{Pt}^{-1}}{ }^{-1}$, even higher than $\mathrm{Pt} / \mathrm{C}$. The higher mass activity of this nanowire structure in the electrode can be ascribed to two factors: (i) the scaffolding effect, which partially mitigates the severe stacking of the 2D rGO nanosheets, thus improving the mass transfer performance; and (ii) the excellent specific catalytic activity from the special surface properties of the unique nanowires $[6,8]$. The improvement of the nanowire scaffolding effect and the mass transfer limitation of rGO-based electrodes are further confirmed in Figure $3 b$. The mass transfer impedance of $\mathrm{Pt}(\mathrm{NW}) \mathrm{Pd} / \mathrm{rGO}$ is much lower than $\mathrm{Pt} / \mathrm{rGO}$, but still higher than $\mathrm{Pt} / \mathrm{C}$ in the MEAs, as shown in Figure 3c.
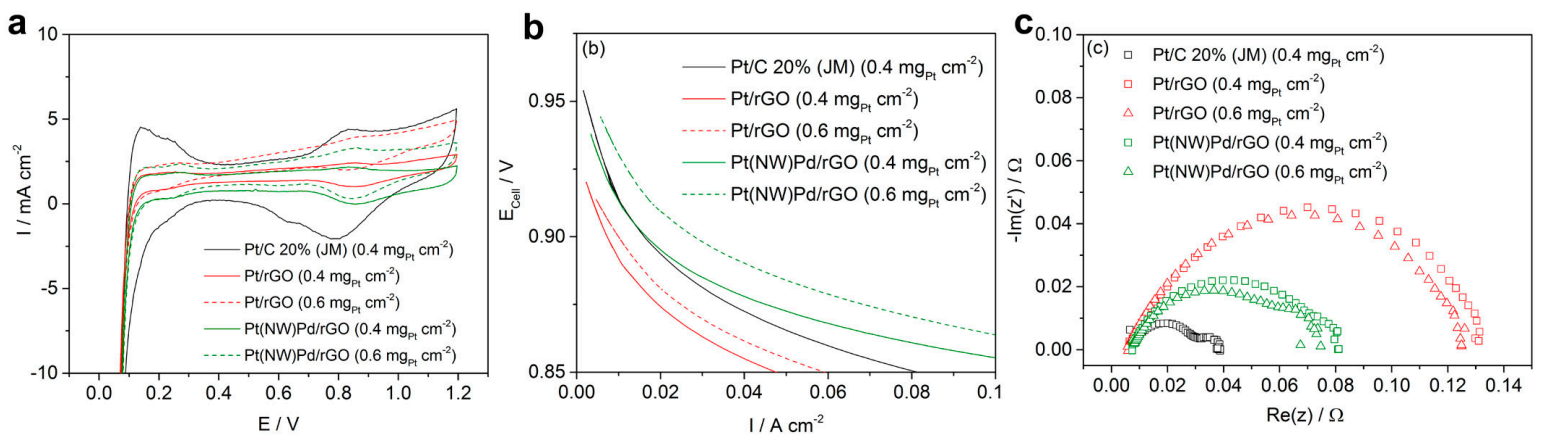

Figure 3. (a) Cathode cyclic voltammetry (CV) scan between $0.05-1.2 \mathrm{~V}$ at a sweep rate of $20 \mathrm{mV} \mathrm{s}^{-1}$ with a cell temperature of $80^{\circ} \mathrm{C}$. The reactant gases are fully humidified $\mathrm{H}_{2}$ at the anode and $\mathrm{N}_{2}$ at the cathode with backpressure of $0.5 / 0.5$ bars and stoichiometry of $1.3 / 2.4$, respectively. (b) Resistance and $\mathrm{H}_{2}$ crossover corrected polarization curves obtained at a sweep rate of $1 \mathrm{mV} \mathrm{s}^{-1}$ at the cell temperature of $80{ }^{\circ} \mathrm{C}$. The reactant gases are fully humidified $\mathrm{H}_{2}$ at the anode and $\mathrm{O}_{2}$ at the cathode with backpressure of $0.5 / 0.5$ bars and stoichiometry of 2/9.5, respectively. (c) EIS spectra at $0.65 \mathrm{~V}$ with amplitude $10 \mathrm{mV}$ in the frequency range $10 \mathrm{kHz}-0.1 \mathrm{~Hz}$ for cells with air as the reactant gas (the same settings as for Figure 2a).

Table 1. ECSA, specific (S.A.) and mass activities (M.A.) of the catalysts in membrane electrode assembly in single cells (derived from Figure $3 a, b$ ).

\begin{tabular}{|c|c|c|c|c|c|}
\hline Cathode & $\begin{array}{l}\text { Power Density } \\
(0.6 \mathrm{~V})\left[\mathrm{W} \mathrm{cm} \mathrm{cm}^{-2}\right]\end{array}$ & $\begin{array}{c}\text { ECSA } \\
{\left[\mathrm{m}^{2} \mathrm{~g}_{\mathrm{Pt}^{-1}}{ }^{-1}\right]}\end{array}$ & $i_{0.9 \mathrm{~V}}[\mathrm{~mA}]$ & $\begin{array}{c}\text { S.A. } \cdot 0.9 \mathrm{~V} \\
{\left[\mu \mathrm{A} \mathrm{cm}^{-2}\right]}\end{array}$ & $\begin{array}{c}\text { M.A. }{ }_{0.9 \mathrm{~V}} \\
{\left[\mathrm{~A} \mathrm{mg}_{\mathrm{Pt}}{ }^{-1}\right]}\end{array}$ \\
\hline $\mathrm{Pt} / \mathrm{C} 20 \%(\mathrm{JM})\left(0.4 \mathrm{mg}_{\mathrm{Pt}} \mathrm{cm}^{-2}\right)$ & 0.314 & 19.84 & 263.520 & 208 & 0.041 \\
\hline $\mathrm{Pt} / \mathrm{rGO}\left(0.4 \mathrm{mg}_{\mathrm{Pt}} \mathrm{cm}^{-2}\right)$ & 0.128 & 2.65 & 104.480 & 616 & 0.016 \\
\hline $\mathrm{Pt} / \mathrm{rGO}\left(0.6 \mathrm{mg}_{\mathrm{Pt}} \mathrm{cm}^{-2}\right)$ & 0.132 & 2.22 & 146.720 & 689 & 0.015 \\
\hline $\mathrm{Pt}(\mathrm{NW}) \mathrm{Pd} / \mathrm{rGO}\left(0.4 \mathrm{mg}_{\mathrm{Pt}} \mathrm{cm}^{-2}\right)$ & 0.206 & 2.97 & 278.560 & 1466 & 0.044 \\
\hline $\mathrm{Pt}(\mathrm{NW}) \mathrm{Pd} / \mathrm{rGO}\left(0.6 \mathrm{mg}_{\mathrm{Pt}} \mathrm{cm}^{-2}\right)$ & 0.226 & 2.71 & 453.920 & 1744 & 0.047 \\
\hline
\end{tabular}

\section{Discussion}

In the fabrication of PEMFC electrodes, the catalyst ink is coated onto the GDL or membrane surface. In the drying process, the organic solvent (e.g., IPA) in the catalyst ink is evaporated, leaving a porous catalyst layer $[1,20]$. However, the $2 \mathrm{D}$ graphene nanosheets tend to stack on top of each other and overlap to form a dense structure within the catalyst layer, which blocks the diffusion of 
the reactant gas and the removal of the produced water in operating PEMFCs and causes poor power performance. Even by increasing the catalyst loading in the electrodes, an effective improvement of the power performance is not achieved because of the mass transfer limitation. Thus, the conclusion is usually drawn that 2D graphene-based materials are not suitable as catalyst supports for practical electrodes in PEMFC devices, despite the much better activities that were observed by the liquid half-cell RDE measurement, where the influence of the mass transfer can nearly be ignored [16].

Nanowires have a large aspect ratio. When they are grown on a 2D nanosheet surface, the unique geometry can form scaffold-like structures and thus partially release the stacking influence of the nanosheets. In fact, in graphene-related research, this function has been used by Si et al. [18] to exfoliate graphene sheets by the use of Pt nanoparticles. In their work the presence of Pt nanoparticles impregnated on the surface of graphene showed a surface area (obtained by BET measurements) around 20 times larger than the graphene without Pt. This scaffolding effect in the nanowire/rGO electrode similarly improves the mass transfer performance within the catalyst layer and an even higher power density is achieved than with $\mathrm{Pt} / \mathrm{C}$ at a low current density range (Figure 2a). However, the rGO nanosheets usually have a much larger size (on the micrometer scale, as shown in Figure 1 and [15]) than the length of Pt nanowires (usually 20-200 nm), so, along with the difficulty of nanowires covering the entire surface of every rGO nanosheet, the stacking of rGO still cannot be fully avoided. Therefore, the improvement of this scaffolding effect is still limited. The stacking and overlapping effects caused by the large rGO nanosheets dominates the structures of the electrodes; even with nanowires, large cracks can still not form as with $\mathrm{Pt} / \mathrm{C}$ nanoparticle catalysts, and quite similar electrode structures are observed in SEM for electrodes made of both $\mathrm{Pt} / \mathrm{rGO}$ and $\mathrm{Pt}(\mathrm{NW}) \mathrm{Pd} / \mathrm{rGO}$ (Figure 1). When the fuel cell is operated at a large current density, as shown in Figure 2a, the amount of reactant gas required for the reaction and the water produced increased dramatically; thus, the scaffolding space provided by the aligned nanowires between the rGO nanosheets is insufficient and thus poor power performance is observed again. This finally causes a clear crossover of the polarization curves of the two MEAs from $\mathrm{Pt}(\mathrm{NW}) \mathrm{Pd} / \mathrm{rGO}$ and $\mathrm{Pt} / \mathrm{C}$, as shown in Figure 2a. This also leads to another suggestion that if a large enough scaffolding effect can be introduced to the electrode structure to avoid the stacking and overlapping to form similar large cracks as that of $\mathrm{Pt} / \mathrm{C}$, e.g., by a further increase of the nanowire length and the improvement of their distribution on the rGO surface, or by reducing all rGO nanosheets to a relative smaller size, or through investigating new alternative electrode preparation methods [21,22], high power performance is still possible for rGO-based electrodes for PEMFCs in real-life operation. Such pursuits are of particular importance when considering the improved resistance of nanowires to coarsening in comparison to $\mathrm{Pt} / \mathrm{C}$ nanoparticle catalysts $[23,24]$ and the enhanced resistance of rGO supports to carbon corrosion [25], both major limitations in the commercial viability of PEMFCs.

\section{Conclusions}

In this work, we evaluated the catalyst electrodes made from $\mathrm{Pt}(\mathrm{NW}) \mathrm{Pd} / \mathrm{rGO}$ and $\mathrm{Pt} / \mathrm{rGO}$ in PEMFCs and the results were compared to $\mathrm{Pt} / \mathrm{C}$ nanoparticle catalysts. The results demonstrated that the introduction of rGO-based catalysts tended to form a dense structure within the catalyst layer that limited the mass transfer in fuel cell operation and finally resulted in poor power performance. The aligned nanowires grown on rGO surface can work as a scaffold, thus improving the mass transfer limitation. At $0.6 \mathrm{~V}$, power densities of 0.206 and $0.128 \mathrm{~W} \mathrm{~cm}^{-2}$ were obtained for $\mathrm{Pt}(\mathrm{NW}) \mathrm{Pd} / \mathrm{rGO}$ and $\mathrm{Pt} / \mathrm{rGO}$ electrodes, respectively, at the catalyst loading of $0.4 \mathrm{mg}_{\mathrm{Pt}} \mathrm{cm}^{-2}$. The mass activity for $\mathrm{Pt}(\mathrm{NW}) \mathrm{Pd} / \mathrm{rGO}$ was $0.044 \mathrm{~A} \mathrm{mg}_{\mathrm{Pt}}{ }^{-1}$ in MEA, which is much higher than $0.016 \mathrm{~A} \mathrm{mg}_{\mathrm{Pt}}{ }^{-1}$ of the $\mathrm{Pt} / \mathrm{rGO}$, and even better than $0.041 \mathrm{~A} \mathrm{mg}_{\mathrm{Pt}^{-1}}{ }^{-1}$ for $\mathrm{Pt} / \mathrm{C}$. However, the power density obtained for the nanowire/rGO electrode is still lower than $\mathrm{Pt} / \mathrm{C}$ at $0.6 \mathrm{~V}$. Nevertheless, this work demonstrates the possibility of using graphene-based materials as a catalyst support for fuel cell devices. To really bring this technology into practical application, further study is required to understand the complicated 
influences of the nanowire length, distribution on $\mathrm{rGO}$, size and structure of $\mathrm{rGO}$, and electrode preparation method.

Acknowledgments: This work was funded by the EPSRC Centre for Doctoral Training in Fuel Cells and their Fuels (EP/L015749/1).

Author Contributions: Shangfeng $\mathrm{Du}$ and Peter Mardle conceived and designed the experiments; Oliver Fernihough performed the experiments; Peter Mardle and Oliver Fernihough analyzed the data; Shangfeng Du and Peter Mardle wrote the paper.

Conflicts of Interest: The authors declare no conflict of interest. The founding sponsors had no role in the design of the study; in the collection, analyses, or interpretation of data; in the writing of the manuscript, and in the decision to publish the results.

\section{References}

1. Gasteiger, H.A.; Kocha, S.S.; Sompalli, B.; Wagner, F.T. Activity benchmarks and requirements for Pt, Pt-alloy, and non-Pt oxygen reduction catalysts for PEMFCs. Appl. Catal. B Environ. 2005, 56, 9-35. [CrossRef]

2. Office of Energy Efficiency and Renewable Energy. Fuel Cell Technologies Office Multi-Year Research, Development, and Demonstration Plan. Section 3.4: Fuel Cells; US Department of Energy: Washington, DC, USA, 2016.

3. Norskov, J.K.; Rossmeisl, J.; Logadottir, A.; Lindqvist, L.; Kitchin, J.R.; Bligaard, T.; Jonsson, H. Origin of the overpotential for oxygen reduction at a fuel-cell cathode. J. Phys. Chem. B 2004, 108, 17886-17892. [CrossRef]

4. Nie, Y.; Li, L.; Wei, Z.D. Recent advancements in Pt and Pt-free catalysts for oxygen reduction reaction. Chem. Soc. Rev. 2015, 44, 2168-2201. [CrossRef] [PubMed]

5. Lu, Y.X.; Du, S.F.; Steinberger-Wilckens, R. One-dimensional nanostructured electrocatalysts for polymer electrolyte membrane fuel cells-A review. Appl. Catal. B 2016, 199, 292-314. [CrossRef]

6. Sun, S.H.; Jaouen, F.; Dodelet, J.P. Controlled Growth of Pt Nanowires on Carbon Nanospheres and Their Enhanced Performance as Electrocatalysts in PEM Fuel Cells. Adv. Mater 2008, 20, 3900-3904. [CrossRef]

7. Lu, Y.X.; Du, S.F.; Steinberger-Wilckens, R. Temperature-controlled growth of single-crystal Pt nanowire arrays for high performance catalyst electrodes in polymer electrolyte fuel cells. Appl. Catal. B 2015, 164, 389-395. [CrossRef]

8. Du, S.F.; Lin, K.J.; Malladi, S.K.; Lu, Y.X.; Sun, S.H.; Xu, W.; Steinberger-Wilckens, R.; Dong, H.S. Plasma nitriding induced growth of Pt-nanowire arrays as high performance electrocatalysts for fuel cells. Sci. Rep. 2014, 4, 6439. [CrossRef] [PubMed]

9. Antolini, E. Carbon supports for low-temperature fuel cell catalysts. Appl. Catal. B 2009, 88, 1-24. [CrossRef]

10. Castanheira, L.; Dubau, L.; Mermoux, M.; Berthome, G.; Caque, N.; Rossinot, E.; Chatenet, M.; Maillard, F. Carbon Corrosion in Proton-Exchange Membrane Fuel Cells: From Model Experiments to Real-Life Operation in Membrane Electrode Assemblies. ACS Catal. 2014, 4, 2258-2267. [CrossRef]

11. Wildgoose, G.G.; Banks, C.E.; Compton, R.G. Metal nanoparticles and related materials supported on carbon nanotubes: Methods and applications. Small 2006, 2, 182-193. [CrossRef] [PubMed]

12. Zheng, J.S.; Wang, M.X.; Zhang, X.S.; Wu, Y.X.; Li, P.; Zhou, X.G.; Yuan, W.K. Platinum/carbon nanofiber nanocomposite synthesized by electrophoretic deposition as electrocatalyst for oxygen reduction. J. Power Sources 2008, 175, 211-216. [CrossRef]

13. Jafri, R.I.; Rajalakshmi, N.; Ramaprabhu, S. Nitrogen doped graphene nanoplatelets as catalyst support for oxygen reduction reaction in proton exchange membrane fuel cell. J. Mater. Chem. 2010, 20, 7114-7117. [CrossRef]

14. Luo, Z.M.; Yuwen, L.H.; Bao, B.Q.; Tian, J.; Zhu, X.R.; Weng, L.X.; Wang, L.H. One-pot, low-temperature synthesis of branched platinum nanowires/reduced graphene oxide (BPtNW/RGO) hybrids for fuel cells. J. Mater. Chem. 2012, 22, 7791-7796. [CrossRef]

15. Du, S.F.; Lu, Y.X.; Steinberger-Wilckens, R. PtPd nanowire arrays supported on reduced graphene oxide as advanced electrocatalysts for methanol oxidation. Carbon 2014, 79, 346-353. [CrossRef]

16. Antolini, E. Graphene as a new carbon support for low-temperature fuel cell catalysts. Appl. Catal. B 2012, 123, 52-68. [CrossRef]

17. Wang, R.Y.; Higgins, D.C.; Hoque, M.A.; Lee, D.; Hassan, F.; Chen, Z.W. Controlled Growth of Platinum Nanowire Arrays on Sulfur Doped Graphene as High Performance Electrocatalyst. Sci. Rep. 2013, 3, 2431-2437. [CrossRef] [PubMed] 
18. Si, Y.C.; Samulski, E.T. Exfoliated Graphene Separated by Platinum Nanoparticles. Chem. Mater. 2008, 20, 6792-6797. [CrossRef]

19. Vu, T.H.T.; Tran, T.T.T.; Le, H.N.T.; Tran, L.T.; Nguyena, P.H.T.; Nguyen, M.D.; Quynh, B.H. Synthesis of Pt/rGO catalysts with two different reducing agents and their methanol electrooxidation activity. Mater. Res. Bull. 2016, 73, 197-203. [CrossRef]

20. Millington, B.; Du, S.F.; Pollet, B.G. The effect of materials on proton exchange membrane fuel cell electrode performance. J. Power Sources 2011, 196, 9013-9017. [CrossRef]

21. Úbeda, D.; Lobato, J.; Cañizares, P.; Pinar, F.J.; Zamora, H.; Fernández-Marchante, C.M.; Rodrigo, M.A. Using Current Distribution Measurements to Characterize the Behavior of HTPEMFCs. Chem. Eng. Trans. 2014, 41, 229-234. [CrossRef]

22. Mardle, P.; Du, S.F. Materials for PEMFC Electrodes. In Reference Module in Materials Science and Materials Engineering; Hashmi, S., Ed.; Elsevier: Amsterdam, The Netherland, 2017; pp. 1-13, ISBN 978-0-12-803581-8.

23. Sun, S.; Zhang, G.; Geng, D.; Chen, Y.; Cai, M.; Sun, X. A Highly Durable Platinum Nanocatalyst for Proton Exchange Membrane Fuel Cells: Multiarmed Starlike Nanowire Single Crystal. Angew. Chem. Int. Ed. 2011, 50, 422-426. [CrossRef] [PubMed]

24. Lu, Y.X.; Du, S.F.; Steinberger-Wilckens, R. Three-dimensional catalyst electrodes based on PtPd nanodendrites for oxygen reduction reaction in PEFC applications. Appl. Catal. B 2016, 187, 108-114. [CrossRef]

25. Sun, K.G.; Chung, J.S.; Hur, S.H. Durability Improvement of Pt/RGO Catalysts for PEMFC by Low-Temperature Self-Catalyzed Reduction. Nanoscale Res. Lett. 2015, 10, 257-263. [CrossRef] [PubMed]

(C) 2018 by the authors. Licensee MDPI, Basel, Switzerland. This article is an open access article distributed under the terms and conditions of the Creative Commons Attribution (CC BY) license (http:/ / creativecommons.org/licenses/by/4.0/). 